\title{
ISOLATION AND CHARACTERIZATION OF PLANT GROWTH PROMOTING BACTERIA ISOLATED FROM GARLIC (allium sativum).
}

\author{
Isolamento e caracterização de bactérias indutoras de crescimento vegetal de alho (Allium sativum).
}

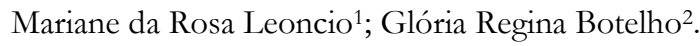 \\ 1 Engenheira agrônoma; Agricultar Consultoria; mariane.rosa.leoncio@gmail.com> \\ 2 Professora; Coordenadoria especial de ciências biologias e agronômicas- CBA; Universidade Federal de Santa Catarina-UFSC \\ campus de Curitibanos; gloria.botelho@ufsc.br.
}

Artigo enviado em 11/02/2017, aceito em 18/07/2017 e publicado em 29/09/2017.

\begin{abstract}
Garlic has great economic and social importance in Santa Catarina. It is a demanding crop in nutrients, being necessary high amount of chemical fertilizers, increasing the cost of production and the environmental impact. An alternative to the use of inputs are Rizobacteria Promoting Plant Growth (RPCP). Among the RPCPs, the most studied genera are Azospirillum, Bacillus and Pseudomonas of the fluorescent group that have shown benefits for the growth of several plant species. In this context, isolates of RPCP obtained from the rhizosphere of garlic maintained in protected cultivation were phenotypically and genotypically characterized and a growth promotion test in vivo was carried out, in protected cultivation. The biochemical tests used for phenotypic characterization were glucose and sucrose fermentation, Methyl Red (MR), catalase production and urea hydrolysis. The potential of plant growth induction was also evaluated by analyzing the production capacity of IAA (Indol-Acetic Acid) and calcium phosphate solubilization in vitro. Twenty-seven isolates were obtained. For the biochemical tests, 21 isolates were able to ferment glucose and 26, sucrose. For the other tests, all isolates showed a positive reaction. As for the mechanisms of plant growth promotion, $81.5 \%$ and $66.6 \%$ of the isolates presented IAA production and phosphate solubilizing capacity, respectively. The in vivo growth promotion test using maize (Zea mays) as a model indicated that the tested isolates (EB02, EB16, EB14, EB26, EB23) showed similarity to the treatment with 100\% recommended nitrogen fertilization. The isolates were identified by sequencing the $16 \mathrm{~S}$ rRNA gene. Fourteen isolates $(51,85 \%$ of the collection) were identified as Bacillus subtillis, including those tested in planta. These microorganisms present potential for the promotion of plant growth.
\end{abstract}

Key words: growth promotion, rizobacteria, liliacea, corn.

Resumo - O alho possui grande importância econômica e social em Santa Catarina. É um cultivo exigente em nutrientes, sendo necessária elevada quantidade de fertilizantes químicos, incrementando o custo de produção e o impacto ambiental. Uma alternativa ao uso de insumos são as Rizobactérias Promotoras de Crescimento de Plantas (RPCP). Dentre as RPCPs, os gêneros mais estudados são Azospirillum, Bacillus e Pseudomonas do grupo fluorescente que têm demonstrado benefícios para o crescimento de várias espécies vegetais. Neste contexto, foram caracterizados, fenotípica e genotipicamente, isolados de RPCP obtidos da rizosfera de alho mantido em cultivo protegido e realizado teste de promoção de crescimento in vivo, também em cultivo protegido. Os testes bioquímicos utilizados para caracterização fenotípica foram fermentação de glicose e sacarose, Vermelho de Metila (VM), produção de catalase e hidrólise da ureia. Também foi avaliado o potencial de indução do crescimento vegetal, mediante análise da capacidade de produção de AIA (Ácido Indol-Acético) e de solubilização de fosfatos de cálcio in vitro. Foram obtidos 27 isolados. Para os testes bioquímicos, 21 isolados foram capazes de fermentar a glicose e 26, a sacarose. Para os demais testes, todos isolados apresentaram reação positiva. Quanto aos mecanismos de promoção de crescimento vegetal, verificouse que $81,5 \%$ e $66,6 \%$ dos isolados apresentaram produção de AIA e capacidade de solubilizar fosfato, respectivamente. O teste de promoção de crescimento in vivo, utilizando milho (Zea mays) como modelo, indicou que os isolados (EB02, EB06, EB14, EB16, EB26) testados apresentaram similaridade com o tratamento com 100\% de adubação nitrogenada recomendada. Os isolados foram identificados por sequenciamento do gene 16S rRNA. Quatorze isolados (51, 85\% da coleção) foram identificados como Bacillus subtillis, incluindo os testados in planta. Estes microrganismos apresentaram potencial para a promoção do crescimento da planta.

Palavras-chave: promoção de crescimento, rizobactérias, liliacea, milho 
REVISTA SCIENTIA AGRARIA

Versão On-line ISSN 1983-2443

Versão Impressa ISSN 1519-1125

SA vol. 18 n .3 Curitiba Jul/Set. 2017 p. 95-106

\section{INTRODUCTION}

Garlic is the fourth most economically important vegetable in Brazil. In addition, there is a social importance, because mainly farmers of small properties (LEONÊEZ, 2008) make its tillage. In the state of Santa Catarina, the cultivation was initially introduced into the Catarinense Plateau region. For many years, the area around the Curitibanos city (Santa Catarina state) had the highest garlic productivity in the state, because it had the favorable geographical and climatical characteristics to the crop (LUCINI, 2008). However, economic and phytosanitary factors led to a decrease in the production. Currently, many efforts are done to increase it, through alternatives methods that can reduce costs, for example, decreasing inputs, like nitrogen fertilizers. Garlic cultivation requires a high nitrogen amount, using approximately $200 \mathrm{~kg} / \mathrm{ha}$ of nitrogen fertilizer, after germination (LUCINI, 2010). Much of this can be lost by leaching process (AGOSTINHO; FERNANDO; CAMEIRA, 2007), causing economic and environmental losses.

The studies related to the decrease of agricultural inputs have been stimulated. Although, trying to maintain the productivity level of the farming areas (BULLA; BALBINOT JUNIOR, 2012). This can be achieved by using the bacteria called Plant Growth Promoting Rhizobacteria (PGPR). The benefits to plants through PGPR can be directly or indirectly performed (VOISARD et al., 1994). The direct effect is a consequence of disponibilization of soil nutrients by PGPR, as Biological Fixation of Nitrogen (MOREIRA et al., 2010), solubilization of mineral phosphates (SANCHEZ LÓPEZ et al., 2014; SOUCHIE; ABBOUD; CAPRONI, 2007). These bacteria can also produce plant hormones, such as Indole-Acetic Acid (IAA) (SANCHEZ LÓPEZ et al., 2014; ANGURO et al., 2014; CATTELAN, 1999). The conversion of tryptophan to IAA is a mechanism performed by several PGPR, since it contributes to the reduction of the excess of this amino acid in the rhizosphere, which can be deleterious to bacterial cells (BRUNETTA et al., 2010).

Several genera of rhizobacteria have already been described, interacting with different plants. The most studied genera are rhizobia, Azospirillum, Bacillus and fluorescent Pseudomonas, that stimulate diverse plants in their development, from the germination until the production, reinforcing sustainable agriculture (HUNGRIA; NOGUEIRA; ARAÚJO, 2016; HUNGRIA; NOGUEIRA; ARAÚJO, 2013; VOGEL et al, 2013; REPKE et al 2013; FIORINI et al 2012; FILHO, 2010; MOREIRA et al., 2010; SILVEIRA, 2007; HUNGRIA et al., 2001). In addition, some isolates of the genera can suppress phytopathogens (LUDWIG; MOURA; GOMES, 2013; LUDWIG et al.,
2009) by producing secondary metabolites, such as siderophores and antibiotics (BOTELHO; MENDONÇA-HAGLER, 2006; VOYARD et al., 1994; LOPER, 1991). Several reports of the plant development improvement, such as corn, beans, cotton, soybeans and rice inoculated with isolates from genera Bacillus and fluorescent Pseudomonas are described (FERREIRA; KNUPP; MARTIN-DIDONET, 2014; CHAVES; ZUCARELI; JUNIOR, 2013; SILVA, 2013; ASSUNPÇÃO et al., 2009; ARAUJO, 2008; LAZZARETI MELO, 2005; ARAÚJO; HUNGRIA, 1999). These reports emphasize the potential use of these rhizobacteria to a larger spectrum of plants.

There is a few information of the rhizobacteria interaction to plants of the Liliaceae family. Marcuzzo, Cezar e Scolaro (2008) evaluated the colonization of 53 rhizobacteria isolated from different parts of garlic. They observed that five of them colonized efficiently (rates between $95,8 \%$ to $66,7 \%$ ) the rhizosphere of two cultivars. It can suggest that PGPR influences the development and growth of the garlic. Some fluorescent Pseudomonas isolates from garlic's rhizosphere solubilized phosphate, produced IAA, were able to fix Nitrogen and inhibited the eclosion of Meloidogyne javanica in vitro (TURATTO; BOTELHO, 2015).

There are few studies of beneficial bacteria association at the garlic culture. For this reason, the objective was to verify, isolate and characterize bacterial groups and evaluate their potential and efficiency in promoting in vitro plant growth.

\section{MATERIAL AND METHODS}

The soil was collected from Dias farm, in the locality of Horizolândia, around Curitibanos (SC). It was classified as Cambissolo associated to Bruno Nitossolo (Embrapa, 1998) and the withdrawal carried out according to the procedures described by the Comissão de Química e Fertilidade de Solo (2004). Garlic bulbs were planted in two pots of 5L containing the soil. Each pot was watered with $50 \mathrm{~mL}$, four times a week.

\section{Isolation of $\mathrm{N}$-fixing rhizobacteria.}

After four weeks, soil and root samples were taken for bacteria isolation. Ten grams of soil sample of each pot were homogenized and weighed. Each one was transferred to flasks containing $90 \mathrm{~mL}$ sterile $0.9 \%$ saline that was stirred for $30 \mathrm{~min}$ at $150 \mathrm{rpm}$. After carrying out the serial dilution, $0.1 \mathrm{~mL}$ of $10^{3}, 10^{4}$ and $10^{5}$ dilutions were transferred to penicillin flasks containing $5 \mathrm{~mL}$ of semi-solid NFB medium (DOBEREINER et al., 1995). For each dilution, there were three replicates, incubated at $28^{\circ} \mathrm{C}$ for seven days. After this period, the presence of the bacteria could be verified by a pellicle in 
REVISTA SCIENTIA AGRARIA

Versão On-line ISSN 1983-2443

Versão Impressa ISSN 1519-1125

SA vol. 18 n $^{\circ} .3$ Curitiba Jul/Set. 2017 p. 95-106

the surface region. The Most Probable Number (MPN), using the McCrady's table for three replicates, evaluated the bacterial population. Then, the colonies were purified, as it will be described below.

For the isolation of the bacteria from the root, $10 \mathrm{~g}$ of root of each pot were taken and disinfected by immersion in 10\% bleach for 10 minutes, followed by three washes in sterile distilled water. Root samples were macerated and transferred to flasks containing and transferred to flasks containing $90 \mathrm{~mL}$ sterile $0.9 \%$ saline and similar procedures described above for soil sample were carried out.

The colonies purification consisted in transferring them to semi-solid NFB medium, four times. After this, the bacteria were grown onto solid NFB medium to obtain pure colonies. The pure cultures were stored at $-20^{\circ} \mathrm{C}$ in cryotubes containing $40 \%$ glycerol.

Phenotypical characterization of isolates and potential for growth promotion of plants.

The phenotypic characterization observed morphological and biochemical features. Colonies morphological characteristics, such as diameter, border, shape, elevation and transparency of the isolates colonies were analyzed. Isolates were grown in Luria Bertani solid medium (LB) at $30^{\circ} \mathrm{C}$, for $24 \mathrm{~h}$.

The biochemical trials performed were Gram test, glucose and sucrose fermentation, catalase and urease production and methyl red (DÖBEREINER et al., 1999). Bacteria were grown in liquid LB medium for 24 hours at $30^{\circ} \mathrm{C}$. For fermentation, urease and methyl red tests, an aliquot was transferred to the tubes containing specific media for each test (RIBEIRO; STELATO, 2011) in three replicates. These were incubated at $30^{\circ} \mathrm{C}$ for 48 hours. To determine the presence of the enzyme catalase, the samples were transferred to microscopic slides. Drops of $\mathrm{H}_{2} \mathrm{O}_{2}$ were added on them, and bubble formation were observed for positive result.

For the isolates plant growth induction potential, the phosphate solubilization capacity and IAA production were determined. To evaluate the solubilization capacity, a medium containing tribasic calcium phosphate $(10 \mathrm{~g} / \mathrm{L}$ glucose; $5 \mathrm{~g} / \mathrm{L}$ NH4Cl; $1 \mathrm{~g} / \mathrm{L}$ $\mathrm{MgSO}_{4} .7 \mathrm{H}_{2} \mathrm{O} ; 4 \mathrm{~g} / \mathrm{L} \mathrm{Ca} 5(\mathrm{OH})\left(\mathrm{PO}_{4}\right)_{3} ; 15 \mathrm{~g} / \mathrm{L}$ Agar - $\mathrm{pH}$ $=6.5)$ was used. The isolates were previously grown in liquid $\mathrm{LB}$ medium at $30^{\circ} \mathrm{C}$ for 24 hours. Then, $0.1 \mathrm{ml}$ of the bacterial suspension was transferred to plates containing the phosphate medium, establishing four isolates per plate, arranged at equidistant points, with five replicates. After incubation at $30^{\circ} \mathrm{C}$ for seven days, the solubilizing capacity of phosphate was evaluated by the presence of colorless halo around the colonies.
The IAA production was evaluated using a colorimetric method described by Bric et al. (1991), with modifications. For this, each isolate was inoculated in tubes containing $2 \mathrm{~mL}$ of liquid $\mathrm{LB}$ medium. The tubes were incubated for $24 \mathrm{~h}$ at $30^{\circ} \mathrm{C}$. After this, they were shaken at $150 \mathrm{rpm}$ for five minutes. Subsequently, Salkowski's solution (CATTELAN, 1999) was added to each tube and incubated at room temperature in the dark for 2 hours. It was observed color change to pink, as positive reaction.

\section{Potential promotion of plant growth in vivo.}

The corn was chosen as a model for growth promotion analysis, due to the large number of studies of the effect of PGPR on it (DARTORA et al., 2013; CARREIRA et al., 2012; CHAVES, 2013, QUADRADO et al., 2014) and because it is widely used in rotation with the garlic by the farmers of Curitibanos region, suggesting PGPR isolates effects to the two plants.

Five isolates (EB02, EB23, EB14, EB16 and EB26) were chosen by the ability to solubilize phosphate and to produce IAA, in addition to the biological fixation of $\mathrm{N}$, for the in vivo experiment. There were eight treatments: five treatments containing the seeds inoculation with each selected isolate and three noninoculated treatments, containing $0 \%, 50 \%$ and $100 \%$ of the amount of $\mathrm{N}$ recommended for the crop, respectively. The source of $\mathrm{N}$ was $\mathrm{KNO}_{3}$ based on the solution of Hoagland and Arnon (1950). The experimental design was in randomized blocks with three replicates.

To the inoculum, flasks containing $250 \mathrm{~mL}$ of LB liquid medium were inoculated with each isolate that were grown at $30^{\circ} \mathrm{C}$ for $24 \mathrm{~h}$. The seeds were previously disinfected by a wash in ethanol $95 \%$, followed by immersion in $10 \%$ sodium hypochlorite solution for $3 \mathrm{~min}$, and then washed three times with sterile distilled water. Then, 20 seeds were dropped into each flask and kept for $1 \mathrm{~h}$, in the laminar flow chamber. For the noninoculated treatments, the seeds were immersed in LB liquid medium without inoculation. Finally, the seeds were laid on paper towel for drying for $1 \mathrm{~h}$, in the laminar flow chamber.

The pots used for sowing contained $5 \mathrm{~kg}$ of the mixture of $50 \%$ vermiculite, $25 \%$ sand and $25 \%$ crushed stones. Each pot received four seeds from each treatment. Every 48 hours, the pots received $50 \mathrm{~mL}$ sterile distilled water for irrigation. After seven days of the sowing, started the application of the nutrient solution, based on HOAGLAND and ARNON (1950) that was applied once a week to each pot. When the corn plants reached the V3 stage, thinning was performed, leaving only two plants per pot. 
After 90 days of the sowing, the plants were collected and analyzed the following parameters: plant height in centimeters (which comprised the distance between the substrate surface region and the insertion of the last expanded leaf); wet weights of root and stem; Dry weights of root and stem (kept in the drying oven at $50^{\circ} \mathrm{C}$ for 72 hours). Data were submitted to analysis of variance and, if there was a significant difference, to the Tukey and Scott-Knott mean tests, with a significance level of $5 \%$, using the statistical program $\mathrm{R}$.

\section{Isolates identification}

All isolates were submitted to $16 \mathrm{~S}$ rRNA gene sequencing, for determination of genera and/ or species. This procedure was carried out at EmbrapaAgrobiology (Seropédica - RJ).

\section{RESULTS AND DISCUSSION}

\section{Phenotypical evaluations of the isolates}

Twenty - seven diazotrophic isolates from the roots were obtained. There were no isolates from the soil. Through the semi-solid NFB medium, an environment with low oxygen level is created and there is no nitrogen present, like soil or plant conditions, where diazotrophic bacteria associated with plant roots are located. In the medium, the bacteria move to the center where the diffusion rate of $\mathrm{O}_{2}$ is in equilibrium with the rate of respiration of the bacteria. Upon reaching a high concentration of cells, the $\mathrm{O}_{2}$ flow occurs, activating the nitrogenase (DÖBEREINER et al, 1995) and forming a pellicle.

Despite the phenotypic analyzes developed were not sufficient for identification of the isolates. However, they were important to indicate that these characteristics are similar to those observed at bacterial genera, commonly found among rhizobacteria, especially Azospirillum, Bacillus and Pseudomonas of fluorescent group (GOMES, 2015; LIMA, 2010; SILVA; FELIPE; BACH, 2004; HOLT et al., 1994), capable of Biological Fixation of Nitrogen (BFN). Some tests, such as the Gram staining test carried out on very young culture of Bacillus, can lead to unreliable reactions, hindering the identification of bacteria and the choice of appropriate biochemical tests. Initially, several isolates showed negative reaction in Gram test and these were subsequently identified by sequencing.

The morphological structure of the colonies data are in table 1 . Colony color of all the isolates was white. Fifteen of them $(55.5 \%)$ were opaque white and $12(44.5 \%)$, translucent white. The diameter of the colonies ranged from 0.5 to $4 \mathrm{~mm}$. The predominant shape was circular form (25 from 27 isolates - 92.6\%). Only two isolates presented rhizoid colony form. Majority of the isolates $81 \%$ presented smooth border colonies. Only five (19\%) exhibited corrugated border. Regarding the elevation of the colonies, fifteen (55.5\%) were convex and $12(44.5 \%)$ flat.

Table 1 - Colonies characterization of bacteria isolated from garlic.

\begin{tabular}{|c|c|c|c|c|c|}
\hline Isolated & $\begin{array}{c}\text { Color } \\
\text { (Whith) }\end{array}$ & Diameter & Shape & Border & Elevation \\
\hline $5 \mathrm{E} 22$ & Opaque & 0,5 & Circular & Smooth & Convex \\
\hline $5 \mathrm{E} 31$ & Opaque & 0,5 & Circular & Smooth & Flat \\
\hline 3E32 & Translucent & 1 & Circular & Corrugated & Flat \\
\hline 4E12 & Translucent & 4 & Circular & Smooth & Flat \\
\hline 4E22 & Opaque & 1 & Circular & Smooth & Convex \\
\hline 3E13 & Translucent & 0,5 & Circular & Smooth & Flat \\
\hline 4E21 & Opaque & 1 & Circular & Smooth & Convex \\
\hline 3E14 & Opaque & 1 & Circular & Smooth & Convex \\
\hline $4 \mathrm{E} 23$ & Opaque & 3 & Rizhoidal & Corrugated & Flat \\
\hline 4E13 & Translucent & 1 & Circular & Smooth & Flat \\
\hline 4E212 & Opaque & 1 & Circular & Smooth & Convex \\
\hline $4 \mathrm{E} 32$ & Opaque & 0,5 & Circular & Smooth & Flat \\
\hline $5 \mathrm{E} 32$ & Translucent & 3 & Rizhoidal & Corrugated & Convex \\
\hline 3E31 & Translucent & 0,5 & Circular & Smooth & Convex \\
\hline $5 \mathrm{E} 21$ & Opaque & 0,5 & Circular & Smooth & Flat \\
\hline $5 \mathrm{E} 34$ & Opaque & 1 & Circular & Smooth & Convex \\
\hline $3 \mathrm{E} 21$ & Opaque & 1 & Circular & Smooth & Convex \\
\hline 3E11 & Translucent & 1 & Circular & Smooth & Convex \\
\hline $5 \mathrm{E} 331$ & Translucent & 3 & Circular & Corrugated & Flat \\
\hline $4 \mathrm{E} 33$ & Translucent & 0,5 & Circular & Smooth & Flat \\
\hline $5 \mathrm{E} 23$ & Opaque & 1 & Circular & Smooth & Convex \\
\hline 4E211 & Translucent & 0,5 & Circular & Smooth & Flat \\
\hline 3E13 & Opaque & 1 & Circular & Smooth & Convex \\
\hline 5E332 & Opaque & 0,5 & Circular & Smooth & Flat \\
\hline 4E11 & Translucent & 1 & Circular & Corrugated & Convex \\
\hline $4 \mathrm{E} 332$ & Opaque & 2 & Circular & Smooth & Convex \\
\hline 4E 333 & Translucent & 1 & Circular & Smooth & Convex \\
\hline
\end{tabular}

The morphological characteristics observed at the isolates resemble the features of the genera Bacillus, Pseudomonas and Azospirillum (CARDOSO, 2008; GOMES, 2013; BENTO, 2013), rhizobacteria commonly found in several plant species ((HUNGRIA; NOGUEIRA; ARAÚJO, 2016; GOMES, 2013; 
REVISTA SCIENTIA AGRARIA

Versão On-line ISSN 1983-2443

Versão Impressa ISSN 1519-1125

SA vol. 18 n $^{\circ} .3$ Curitiba Jul/Set. 2017 p. 95-106

MOREIRA et al, 2010; BOTELHO; MENDONÇAHAGLER, 2006).

Biochemical evaluations demonstrated that for the glucose and sucrose fermentation test, 21 (78\%) and $26(97 \%)$ of the isolates showed positive reaction, respectively (table 2 ). The results are in agreement with several reports that some rhizobacteria are able to ferment a number of sources of carbon. Bueno (2010) described that Bacillus isolates had the ability to use various sources of carbon, including glucose and sucrose. Bacillus uses glucose to produce acids and hydrolyzes starch (LIMA, 2010). According to Holt et al. (1994), Azospirillum amazonense is the only species of the genus capable of metabolizing different carbon sources, such as glucose and sucrose. Psendomonas also present the potential of using different $\mathrm{C}$ sources (GOMES, 2015) (Table 2).

For the methyl red test, which verified the capacity of producing stable organic acids from the fermentation of glucose, all the isolates obtained positive reaction (Table 2). This test is used to aid in the identification of gram-negative bacterial species (OLIVEIRA, 2000) of Enterobacteriaceae family, such as Pseudomonas.

The catalase presence test indicated that $85,2 \%$ in the isolates (24) were capable of releasing oxygen from hydrogen peroxide (Table 2). All they changed the color of the medium, from yellow to reddish, because of the $\mathrm{pH}$ increase caused by the final products of urea breaks generated by the action of urease (Table 2). These characteristics are similar to those observed at the genera Arospirillum, Pseudomonas and Bacillus (FERREIRA; KNUPP; MARTIN; DIDONET, 2014; GOMES, 2013; SILVA, 2013; MANDELBAUM; ALLAN; WACKETT, 1995).

\section{Evaluation of mechanisms of plant growth promotion in vitro.}

Most of the isolates were able to produce IAA and solubilize phosphate (Table $2 \mathrm{~b}$ ). The results agree with several reports describing these mechanisms as common among PGPR.

The analysis results indicated that 22 of the isolates $(81.5 \%)$ were positive to produce Indol-Acetic Acid (IAA). Kuss (2007) disclosed that Azospirillum helps the plants, not only for $\mathrm{N}_{2}$ fixation, but also by other mechanisms, including the production of phytohormones, such as IAA that benefits root growth. Consequently, there is an increasing of water and nutrients absorption (BONILLA, 2011). Many fluorescent Pseudomonas have the capacity of indole- acid production (VACHERON et al., 2016; COELHO, 2009).
Table 2- Biochemical profile and mechanisms of growth promotion in plants.

\begin{tabular}{|c|c|c|c|c|c|c|c|}
\hline \multirow[t]{2}{*}{ Isolate } & \multicolumn{7}{|c|}{ Fermentation } \\
\hline & Glucose & Sucrose & MR & Catalase & Urease & $\begin{array}{c}\text { IAA } \\
\text { production }\end{array}$ & $\begin{array}{c}\mathrm{P} \\
\text { solubilization }\end{array}$ \\
\hline EB01 & + & + & + & + & + & + & + \\
\hline $\mathrm{EB} 02$ & + & + & + & + & + & - & + \\
\hline EB03 & + & + & + & + & + & + & + \\
\hline EB04 & + & + & + & + & + & + & + \\
\hline EB05 & + & + & + & - & + & + & + \\
\hline EB06 & + & + & + & + & + & - & + \\
\hline ЕВ07 & + & + & + & + & + & + & - \\
\hline EB08 & + & + & + & + & + & + & + \\
\hline ЕВ09 & - & - & + & - & + & + & - \\
\hline EB10 & + & + & + & + & + & + & + \\
\hline EB11 & - & + & + & - & + & - & - \\
\hline EB12 & + & + & + & + & + & + & - \\
\hline EB13 & + & + & + & + & + & + & + \\
\hline EB14 & + & + & + & + & + & + & + \\
\hline EB15 & + & + & + & + & + & - & - \\
\hline EB16 & + & + & + & + & + & + & - \\
\hline EB17 & + & + & + & + & + & + & + \\
\hline EB18 & + & + & + & + & + & + & - \\
\hline EB19 & - & + & + & - & + & + & + \\
\hline EB20 & - & + & + & + & + & + & - \\
\hline EB21 & + & + & + & + & + & + & - \\
\hline EB22 & - & + & + & + & + & + & + \\
\hline EB23 & + & + & + & + & + & + & + \\
\hline EB24 & - & + & + & + & + & + & + \\
\hline EB25 & + & + & + & + & + & + & + \\
\hline EB26 & + & + & + & + & + & + & + \\
\hline EB27 & + & + & + & + & + & + & + \\
\hline
\end{tabular}

* MR - Methyl Red test; (-) Negative reaction.

Andrade (2012) reports that Bacillus can synthesize IAA in banana crop, both by the tryptophandependent pathway and by alternative routes. Sicuia, Dinu e Constantinescu (2016) reported that an IAAproducing Bacillus subtilis isolate increased the germination percent and seedlings vigor of tomato.

The solubilizing capacity trials of calcium phosphate showed that $66.7 \%$ of isolates (18) had positive reaction, i.e., produced transparent halo around the colonies. This capacity can help the plant in several soil conditions. When the insoluble P-Ca form is in the soil, due to the excess of liming, for instance, phosphate- 
REVISTA SCIENTIA AGRARIA

Versão On-line ISSN 1983-2443

Versão Impressa ISSN 1519-1125

SA vol. 18 n $^{\circ} .3$ Curitiba Jul/Set. 2017 p. 95-106

solubilizing bacteria can help plant absorption of this element (TIRLONI, 2006). Rodríguez and Fraga (1999) described that Bacillus and Pseudomonas have the ability to solubilize inorganic phosphate compounds. Kang et al (2014) related that a phosphate solubilizing Bacillus megaterium isolate enhanced the growth of mustard plant and Oteino et al. (2015) reported that phosphate solubilizing Pseudomonas fluorescens L321 strain increased Pisum sativum L. growth. Ayyaz et al (2016) also observed improvement of wheat growth inoculated with Azospirillum strains.

\section{Potential promotion of plant growth in vivo.}

Concerning the plant height, there is a significant difference between without nitrogen fertilization treatments, those with nitrogen fertilization $(100 \%$ and $50 \%$ ) and inoculated treatments (Figures 1a and $1 \mathrm{~b})$. However, inoculated and nitrogen fertilizations treatments did not differ between them, indicating that the isolates in the greenhouse were able to maintain the development of the plant (Figure 1).

\section{Plant height averages}

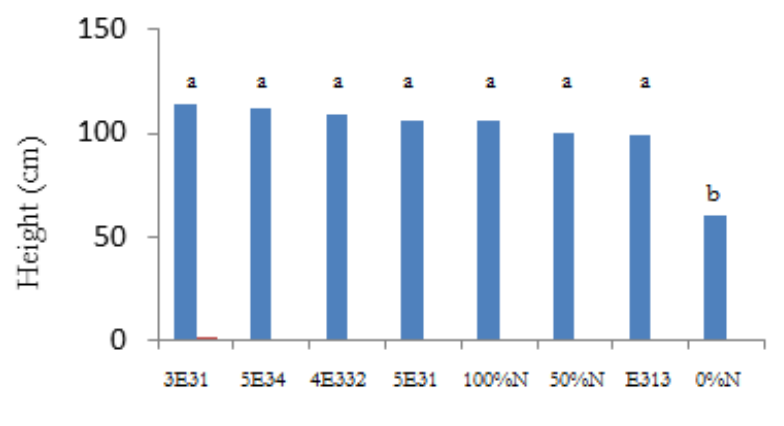

- Average

Figure 1 - Effect of bacteria isolates inoculation at plant height.

These results coincide with others that used PGPR for corn inoculation. The inoculation of B. subtilis OG strain on bean (LAZZARETI; MELO, 2005) provided larger and more vigorous plants. The inoculation significantly stimulated the growth of the crop. The same effect was observed when $A$. brasilense strains (BR11005 - Sp 245, AbV5 and AbV6) (PEDRINHO, 2009; BASI, 2013) were inoculated on corn. De Oliveira et al. (2015) also describes that Pseudomonas fluorescens provided higher corn plant height and ear size.

Regarding the dry and wet weight of the stem, results similar to those obtained with plant height was observed. There was a significant difference between the treatment without Nitrogen fertilization, inoculated treatments and those with $\mathrm{N}$ fertilization. However, there was no significant difference between the latter (Figure 2). The results emphasize again that the isolates can induce plant growth. Possibly, by helping in the nutrients availability, especially in processes such as biological $\mathrm{N}$ fixation, requiring more detailed analysis.

Several studies describe the action of PGPR in mass accumulation by plants. Authors (KUAN et al, 2016; LIMA, 2010; LAZZARETI; MELO, 2005) reported that Bacillus showed a positive effect on the development of beans and corn plants. In corn, $B$ subtilis (PRBS-1 and OG lineage) associated to $\mathrm{N}$ fertilization caused effective responses in growth and grain yield (LIMA, 2010). Inoculation of PGPR strains, such as UPMB10 (Bacillus subtilis) increased in plant- $\mathrm{N}$ uptake, dry biomass and ear yield of maize (Kuan et al, 2016). Ramos et al (2010) mentioned that the interaction of $A$. lipoferum BR 11084 strain on corn showed a significant development as far as nitrogen fertilization. Costa (2015) also observed the positive effect of $A$. brasiliense $\mathrm{Ab}-\mathrm{V} 5$ and $\mathrm{Ab}-\mathrm{V} 6$ strains and nitrogen fertilization association at vegetative growth stage of maize and at dry mass of stalk and leaves. De Oliveira et al. (2015) reported that Pseudomonas supported corn plants in their growth and increased the length and diameter of ears.

Regarding the root wet weight data (Figure 2), the mean test of Scott-Knott was used because there was great variation within treatments. This test aims to homogenize the data within the treatments, minimizing the existing variations (Da SILVA, 2007). Possibly, this great variation was due to the intense root growth during the experiment, which hampered its development inside the pots. This made it impossible to obtain the dry weight of the roots.

However, for the root wet mass it was observed a significant difference between the group formed by the treatments inoculated with the isolates EB02 (T8), EB16 (T7), EB14 (T6) and the total nitrogen fertilization and that formed by the other (isolated EB26 -T5; EB23 - T4 and with half of the nitrogen fertilization).

The isolates EB02 (T8), EB16 (T7), EB14 (T6) did not differ from the total nitrogen fertilization, indicating that they showed similar performance in relation to the root mass accumulation. This suggests that they can induce the plant to produce more roots, increasing the uptake of water and nutrients. Araujo (2008) described the Bacillus subtilis potential for inducing root production in corn, cotton and soybeans. The author reported the possibility that bacteria to enhance the plant nutrition. Hartmann et al. (1983), studying the inoculation with Azospirillum, reported a morphological modification of the corn root system, increasing not only the number of radicels, but also the diameter of the lateral and adventitious roots. 


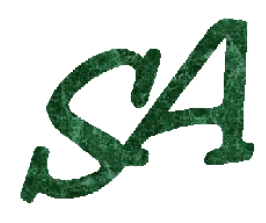

REVISTA SCIENTIA AGRARIA

Versão On-line ISSN 1983-2443

Versão Impressa ISSN 1519-1125

SA vol. $18 \mathrm{n}^{\circ} .3$ Curitiba Jul/Set. 2017 p. 95-106
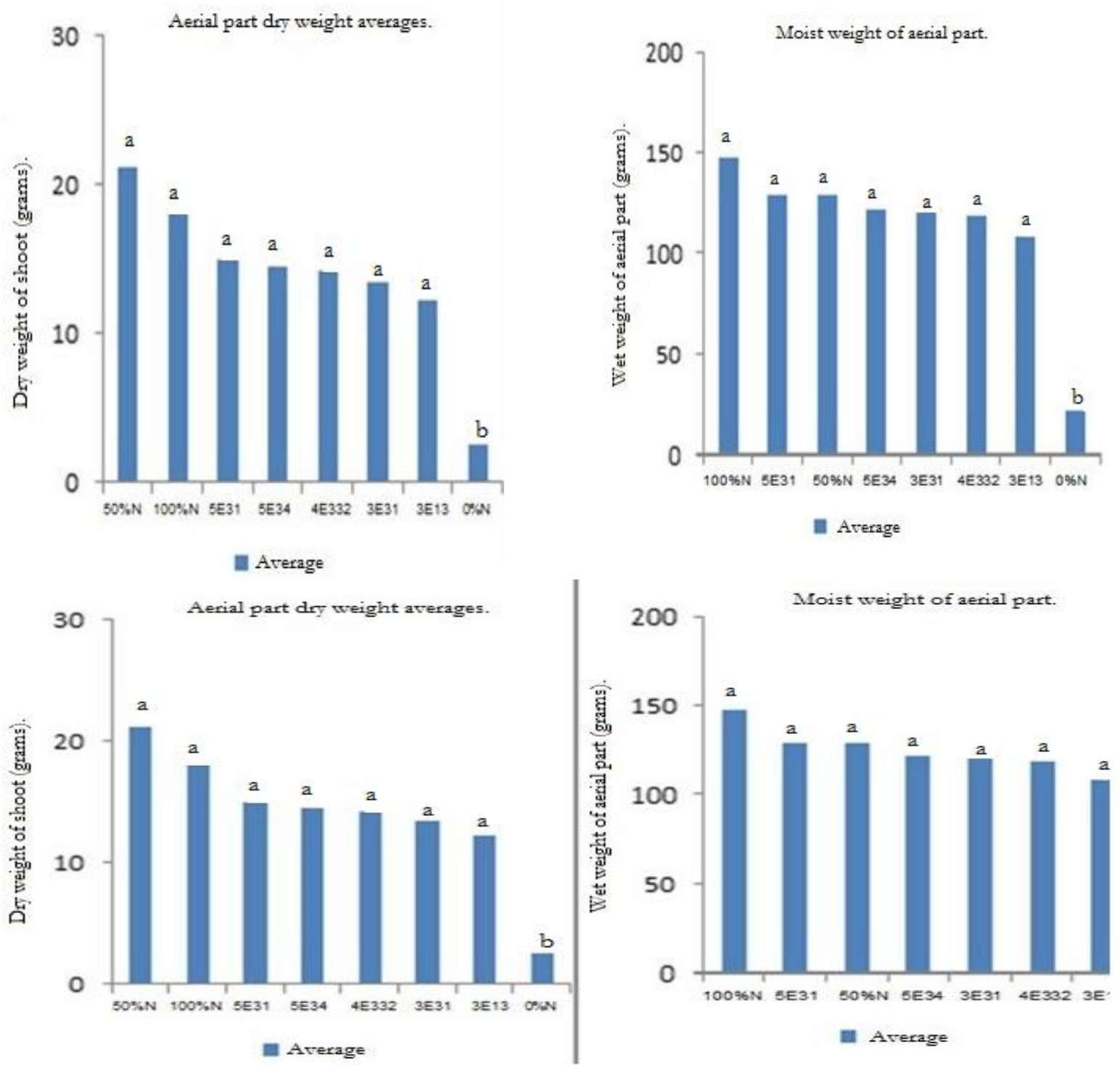

Figure 2 - Effect of inoculation of bacterial isolates on the shoot weight.

\section{Identification of the isolates.}

Sequencing of the 16S rRNA gene of bacteria revealed that 14 isolates belong to Bacillus subtilis species, including the five used for evaluations in planta. The remaining isolates could not yet be identified. The results are in agreement with the phenotypic characterization of the isolates, since many of the characteristics match to those observed in genus Bacillus. Bacillus can fix $\mathrm{N}_{2}$ and this characteristic can be observed initially in bacteria that form pellicule in semi solid NFB medium, as well as the shape of the colony in solid medium (ARAUJO, 1999; FILHO, FERRO, PINHO, 2010), generally is circular, with irregular borders, cream

or white. Andrade (2012) and Lazzaretti and Melo (2005) described the potential B. subtilis for production of IAA and to phosphate solubilization, resembling the results found in the tests in vitro with the isolates. The authors also reported that the bacteria assisted bean and banana plant growth. Several isolates from cowpea nodules grown in the Cerrado were identified as belonging to the genus Bacillus. Those were able to solubilize phosphate and produce IAA in vitro and some 
of them were able to nodulate cowpea roots (Da COSTA et al, 2013).

\section{CONCLUSION}

Phenotypic evaluations are important for the characterization of rhizobacteria. However, some analyzes, such as Gram-test must be done at different stages of the bacterial growth in order to avoid dubious reactions, such as to Bacillus.

The sequencing showed that 14 of the isolates belong to the Bacillus subtilis species. These presented productions of AIA and phosphate solubilization in vitro. Five of these isolates (EB02, EB16, EB14, EB23 and EB26) were tested in vivo and demonstrated potential to promote corn growth, including biological fixation of nitrogen. The evaluated parameters showed similar efficiency to the treatments with $50 \%$ and $100 \%$ of nitrogen fertilization recommended.

\section{ACKNOWLEDGEMENTS}

Dr. Jerri Edson Zilli, Embrapa-Agrobiologia (Seropédica - RJ). Agronomist engineer Roberto de Almeida. Cultivar Insumos Agrícolas (Curitibanos $\mathrm{SC})$.

\section{REFERENCES}

AGOSTINHO, J.; FERNANDO, R.; CAMEIRA, M. R. Avaliação do potencial de redução de lixiviação de nitratos na zona vulnerável $n^{\circ}$. In: II Congresso Nacional de Rega e Drenagem, 2007, Rio de Janeiro, RJ. Fundão. Rio de Janeiro: UFRJ, 2007.

ANDRADE, L. F. Bactérias endofiticas de bananeira "prataanã": fixação de nitrogênio, solubilização de fosfato de cálcio $e$ produção de ácido indol-3-acético. 2012. 67p. Dissertação (Mestrado) - Pós- Graduação em Produção Vegetal no Semiárido, Universidade Estadual de Montes Claros. Janaúba, 2012. Disponível em: http://www.producaovegetal.com.br/arquivos_upload /editor/file/Dissertacao_leandro_andrade.pdf. Acesso em: 04 nov. 2015.

ANGURO, V.C; SANFUENTES, E.A.; RODRÍGUEZ, F.; SOSSA, K.E. Caracterización de rizobacterias promotoras de crecimiento en plántulas de Eucalyptus nitens. Revista Argentina de Microbiología. v. 46, n.4, p. 338-347, 2014.

ARAUJO, F. F. Inoculação de sementes com Bacillus subtilis, formulado com farinha de ostras e desenvolvimento de milho, soja e algodão. Ciência $e$
Agrotecnologia. v.32, n.2, Lavras, Mar./Apr. 2008. Disponível em: bttp://dx.doi.org/10.1590/S141370542008000200017. Acesso em: 14 nov. 2015.

ARAÚJO, F. F.; HUNGRIA, M. Nodulação e rendimento de soja co-infectada com Bacillus subtilis e Bradyrbizobium japonicum / Bradyrbizobium elkanii. Pesquisa Agropecuária Brasileira. Brasília, v.34, n.9, Sept., 1999. Disponível em: http://dx.doi.org/10.1590/S0100204X1999000900014. Acesso em: 14 nov. 2015.

ASSUMPÇÃO, L. C. et al. Diversidade e potencial biotecnológico da comunidade bacteriana endofítica de sementes de soja. Pesquisa Agropecuária Brasileira. Brasília, v.44, n.5, p.503-510, maio 2009. Disponível em: http://www.scielo.br/pdf/pab/v44n5/v44n5a10.pdf. Acesso em: 14 nov. 2015.

AYYAZ, K.; ZAHEER, A.; RASUL, G.; MIRZA, M.S. Isolation and identification by $16 \mathrm{~S}$ rRNA sequence analysis of plant growth-promoting azospirilla from the rhizosphere of wheat. Brazilian journal of microbiology. v.47, p. 542-550, 2016. Disponível em: http://www.scielo.br/pdf/bjm/v47n3/1517-8382bjm-47-03-0542.pdf. Acesso em: 01 de janeiro de 2017.

BASI, S. Associação de Azospirillum brasilense e de nitrogênio em cobertura na cultura do milho. 2013. 50f. Dissertação (Mestrado) - Pós-Graduação em Agronomia, Universidade Estadual do Centro-oeste. Guarapuava, $2013 . \quad$ Disponível em: http://tede.unicentro.br/tde_busca/arquivo.php?codA rquivo $=213$. Acesso em: 23 set. 2015.

BENTO, M. A. O. Prospeçãa e avaliação do potencial biotecnológico de bactérias da serrapilheira e do solo em área de floresta atlântica do norte fluminense. 2013. 109p. Dissertação (Mestrado) - Pós-Graduação em Produção Vegetal, Universidade Estadual do Norte Fluminense. Campos de Goytacazes, 2013. Disponível em: http://docplayer.com.br/11104523-Prospeccao-eavaliacao-do-potencial-biotecnologico-de-bacterias-daserrapilheira-e-do-solo-em-area-de-floresta-atlanticado-norte-fluminense.html. Acesso em: 04 mai. 2017.

BONILLA, G. A. E. Seleção de Bactérias Diazotróficas Solubilizadoras de Fósforo e seu Efeito no Desenvolvimento de Plantas de Arroz. 2011. 85f. Dissertação (Mestrado) Pós-Graduação em Fitotecnia, Universidade Federal Rural do Rio de Janeiro. Seropédica, 2011. Disponível em:

http://cursos.ufrrj.br/posgraduacao/ppgf/files/2013/ 08/Dissertação-PPGF-German-Andrés-EstradaBonilla.pdf. Acesso em: 05 maio 2015. 
BOTELHO, G. R.; MENDONÇA-HAGLER, L. C. Fluorescent pseudomonads associated with the rhizosphere of crops - an overview. Brazilian Journal of Microbiology. v.37, p. 401-416, 2006.

BRUNETTA, J. M. F. C. et al. Isolamento e seleção de rizobactérias para produção de mudas de Pinus taeda. Revista árvore. v. 34, n.3, p.399-406, 2010. Disponível em: http://www.scielo.br/pdf/rarv/v34n3/a03v34n3. Acesso em: 05 maio 2015.

BUENO, S. M. et al. Estudo da produção de biossurfactante em caldo de fermentação. Química nova.v.33, n.7, São Paulo, 2010. Disponível em: http://dx.doi.org/10.1590/S0100-

40422010000700026. Acesso em: 09 nov. 2015.

BULLA, D.; BALBINOT JUNIOR, A. A. Inoculação de sementes de milho com Azospirillum brasiliense em diferentes doses de nitrogênio. Revista Agropecuária Catarinense. v.25, n.2, 2012. Disponível em: http://ainfo.cnptia.embrapa.br/digital/bitstream/item /101915/1/Inoculacao-de-sementes-de-milho-comAzospirillum-brasiliense-em-diferentes-doses-denitrogenio.pdf. Acesso em: 27 set. 2015.

BUGNO, A.; ALMODOVAR, A. A. B.; PEREIRA, T.; AURICCHIO, M. T. Detecção de bactérias gramnegativas não fermentadoras em água tratada para diálise. Revista Instituto Adolfo Lut\%. v.66, n.2, pp. 172-175, $2007 . \quad$ Disponível em: http://periodicos.ses.sp.bvs.br/scielo.php?script=sci_a rttext\&pid=S0073-

98552007000200014\&lng=pt\&nrm=iso. Acesso em: 14 nov. 2015.

COELHO, L. F.; FREITAS, S. S.; MELO, A. M. T.; AMBROSANO, G. M. B. Interação de bactérias fluorescentes do gênero Pseudomonas e de Bacillus spp. com a rizosfera de diferentes plantas. Rev. Bras. Ciênc. Solo. 2007, vol.31, n.6, pp.1413-1420. ISSN 1806-9657. Disponível em: http://dx.doi.org/10.1590/S010006832007000600018. Acesso em: 04 mai. 2017.

CARDOSO, I. C. M. Ocorrência e diversidade de bactérias endofiticas do gênero Azospirillum na cultura do arroz irrigado em Santa Catarina. 2008. Programa de Pós-Graduação em Ciências Agrárias Mestrado em Manejo do Solo, Universidade do Estado de Santa Catarina. Lages, 2008. http://rca.cav.udesc.br/rca_2010_2/7Cardoso.pdf. Acesso em: 02 abr. 2015.

CAVAllet, L. E. et al. Produtividade do milho em resposta à aplicação de nitrogênio e inoculação das sementes com Arospirillum spp. Revista Brasileira de
Engenharia Agricola e Ambiental. v.4, n.1, p.129-132, 2000. Disponível

em: http://www.scielo.br/scielo.php?script=sci_arttext\&pi $\mathrm{d}=\mathrm{S} 1415-43662000000100024$. Acesso em: 25 maio 2015.

CARREIRA, F. S. et al. Efeito da Azospirillum brasiliense na produtividade de milho no sudoeste goiano. In: I CONGRESSO DE PESQUISA E PÓSGRADUAÇÃO DO CAMPUS RIO VERDE DO IFGOIANO, 2012, Rio Verde, GO.: Rio Verde:IFGoiano, $2012 . \quad$ Disponível em: http://rioverde.ifgoiano.edu.br/wpcontent/uploads/dppg/resumos/iniciacao/agronomia /Efeito-da-Azospirillum-brasilense-na-produtividadede-milho-no-sudoeste-goiano.pdf. Acesso em: 26 maio 2015.

CATTELAN, A. J. Métodos quantitativos para determinação de características bioquímicas e fisiológicas associadas com bactérias promotoras do crescimento vegetal. Londrina: Embrapa soja, 1999. 36p. (Embrapa soja. Documentos 139).

CHAVES, D. P.; ZUCARELI, C.; OLIVEIRA JUNIOR. A. Fontes de fósforo associadas à inoculação com Pseudomonas fluorescens no desenvolvimento e produtividade do milho. Semana: Ciências Agrárias, Londrina, v. 34, n. 1, p. 57-72, jan./fev. 2013. Disponível em:

http://www.uel.br/revistas/uel/index.php/semagraria s/article/view/9543. Acesso em: 06 nov. 2015.

COSTA, Raoni Ribeiro Guedes Fonseca et al. Efficiency of inoculant with Azospirillum brasilense on the growth and yield of second-harvest maize. Pesq. Agropec. Trop., Goiânia, v. 45, n. 3, p. 304-311, Jul./Sep. 2015. Disponível em: http://www.scielo.br/scielo.php?script=sci_arttext\&pi $\mathrm{d}=\mathrm{S} 1983-40632015000300006$. Acesso em: 04 mai. 2017.

Da COSTA, E. M.; NÓBREGA, R. S. A; De CARVALHO F.; TROCHMANN, A.; FERREIRA, L. De V.; MOREIRA, F. M. De S. Promoção do crescimento vegetal e diversidade genética de bactérias isoladas de nódulos de feijão- caupi. Pesquisa Agropecuária Brasileira. v.48, n.9, p.1275-1284, 2013. 
Da SILVA, C. M. R. Uso do teste de Scott-Knott e da análise de agrupamentos, na obtenção de grupos de locais para experimentos com cana-de-açucar. 2007. 48p. Dissertação (Mestrado) - Pós-Graduação em Agronomia, Escola Superior de Agricultura "Luiz de Queiroz", Universidade de São Paulo. Piracicaba, 2007.Disponível em:

http://www.teses.usp.br/teses/disponiveis/11/11134/ tde-12032008-

151057/publico/cristianemarianadasilva.pdf. Acesso em: 11 nov. 2015.

DARTORA, J. et al. Adubação nitrogenada associada à inoculação com Azospirillum brasilense e Herbaspirillum seropedicae na cultura do milho. Rev. bras. eng. agríc. ambient., Campina Grande, v. 17, n. 10, p. 1023-1029, Out. 2013. Disponivel em: http://www.scielo.br/scielo.php?script=sci_arttext\&pi $\mathrm{d}=$ S1415-43662013001000001\&lang=pt. Acesso em: 04 mai. 2017.

De OLIVEIRA, M. A. de et al. Adubação fosfatada associada à inoculação com Pseudomonas fluorescens no desempenho agronómico do milho. Revista de Ciências Agrárias, v.38, n.1, 2015. Disponível em: http://www.scielo.mec.pt/pdf/rca/v38n1/v38n1a04.p df. Acesso em: 04 nov. 2015

DÖBEREINER, J.; BALDANI, V. L.; BALDANI, J. I. Como isolar e identificar bactérias diazotróficas de plantas nãoleguminosas. Seropédica: Embrapa Centro Nacional de Pesquisa em Agrobiologia, 1995. 60 p.

DÖBEREINER, J.; ANDRADE, V. de O.; BALDANI, V.L.D. Protocolos para Preparo de Meios de Cultura da Embrapa Agrobiologia. Seropédica: Embrapa Agrobiologia, dez. 1999. 38p. (Embrapa-CNPAB. Documentos, 110).

FERREIRA, E. P. B.; KNUPP, A. M.; MARTINDIDONET, C. C. G. Crescimento de cultivares de arroz (Oryza sativa L.) influenciado pela inoculação com bactérias promotoras de crescimento de plantas. Bioscience Journal. Uberlândia, v. 30, n. 3, p. 655-665, 2014. Disponível em: www.seer.ufu.br/index.php/biosciencejournal/article/ download/18043/13923. Acesso em: 13 nov. 2015.

GOMES, M. J. P. Gênero Bacillus spp. Porto Alegre: Universidade Federal do Rio Grande do Sul. FAVET, 2013. Disponível em: http://www.ufrgs.br/labacvet/files/Gênero Bacillus 42013-1 versão 2013.pdf. Acesso em: 03 nov. 2015.

GOMES, M. J. P. Gênero Pseudomonas spp. Porto Alegre: Universidade Federal do Rio Grande do Sul.
FAVET, $2015 . \quad$ Disponível em: http://www.ufrgs.br/labacvet/ files/Gênero Pseudomonas e Burkholderia 4-2015_1.pdf. Acesso em: 13 nov. 2015.

HARTMANN, A.; MAHAVIR, S.; KLIGMALLER, W. Isolation and characterization of Azospirillum mutants excreting high amounts of indole acetic acid. Canadian Journal of Microbiology. v.29, p.916-922, 1983.

HOAGLAND, D.; ARNON, D.I. The water culture method for growing plants without soil. California Agriculture Experimental Station Circular, 1950. 347 p.

HOLT, J. G.; KRIEG, N. R.; SNEATH, P. H. A.; STALEY, J. T.; WILLIAMS, S. T. Bergey's manual of determinative bacteriology. 9. ed. Baltimore: Williams \& Wilkins, 1994.787 p.

HUNGRIA， M.; CAMPO, R.; CHUEIRE， L.; GRANGE, L.; MEGÍAS, M. Symbiotic effectiveness of fast-growing rhizobial strains isolated from soybean nodules in Brazil. Biology and Fertility of Soils, v.35, p.387394, 2001.

HUNGRIA, M.; NOGUEIRA, M.; ARAUJO, R. Coinoculation of soybeans and common beans with rhizobia and azospirilla: strategies to improve sustainability. Biology and Fertility of Soils, v.49, n.7, p.791801, 2013.

HUNGRIA, M.; NOGUEIRA, M.; ARAUJO, R. Inoculation of Brachiaria spp. with the plant growthpromoting bacterium Arospirillum brasilense: An environment-friendly component in the reclamation of degraded pastures in the tropics. Agriculture, Ecosystems and Environment v.221, p.125-1311, 2016.

KANG, S-M; RADHAKRISHNAN, R.; YOU, Y-H.; JOO, G-J.; LEE, I-J.; LEE, K-E.; KIM, J-H. Phosphate solubilizing Bacillus megaterium mj1212 regulates endogenous plant carbohydrates and amino acids contents to promote mustard plant growth. Indian Journal of Microbiology. v. 54, n.4, p. 427-433, 2014. Disponível em:

https://www.ncbi.nlm.nih.gov/pmc/articles/PMC418 6932/. Acesso em: 01 de janeiro de 2017. 
KUAN, K. B.; OTHMAN, R.; RAHIM, K. A.; SHAMSUDDIN, Z. H. Plant Growth-Promoting Rhizobacteria Inoculation to Enhance Vegetative Growth, Nitrogen Fixation and Nitrogen Remobilisation of Maize under Greenhouse Conditions. PLoS ONE. v.11, n.3, p. 1-19, 2016. Disponível em: http://journals.plos.org/plosone/article/file?id=10.13 71 /journal.pone. $0152478 \&$ type $=$ printable. Acesso em: 12 de janeiro de 2017.

KUSS, A. V. et al. Fixação de nitrogênio e produção de ácido indolacético in vitro por bactérias diazotróficas endofíticas. Pesquisa Agropecuária Brasileira. v.42, n.10, $2007 . \quad$ Disponível em: http://www.scielo.br/scielo.php?script=sci_arttext\&pi $\mathrm{d}=$ S0100-204X2007001000013. Acesso em: 10 abr. 2015.

LAZZARETTI, E.; MELO, I. S. Influência de Bacillus subtilis na Promoção de Crescimento de Plantas e Nodulação de Raízes de Feijoeiro. Jaguariuna: Embrapa Meio Ambiente, 2005. 21p. (Embrapa Meio Ambiente. Boletim de Pesquisa e Desenvolvimento, 28). Disponível em: http://www.cnpma.embrapa.br/download/boletim_28 .pdf. Acesso em: 10 abr. 2015.

LEONÊZ, A. C. Alho: Alimento e Saúde. 2008. 30p. Monografia (Especialização). Pós-Graduação Lato sensu Curso de Especialização em Gastronomia e Saúde. Universidade de Brasília. Brasília, 2008. Disponível em: http://bdm.unb.br/bitstream/10483/327/1/2008_An aClaudiaLeonez.pdf. Acesso em: 27 set. 2014.

LIMA, F. F. et al. Bacillus subtilis e adubação nitrogenada na produtividade do milho. Revista Brasileira de Ciências Agrárias ISSN: 1981-0997v.6, n.4, p.657-661, out.-dez., 2011. Disponível em: http://www.agraria.pro.br/sistema/index.php?journal $=$ agraria\&page $=$ article\&op $=$ view\&path; [ = agraria_v6i4 a1429\&path; [=1022. Acesso em: 04 maio 2017.

LOPER, J. E., BUYER, J. S. Siderophores in microbial interactions on plant surfaces.Molecular plantmicrobeinteraction. v. 4, p. 5-13, 1991.

LUCINI, M. A. O alho no Brasil: um pouco da história dos números do nobre roxo. Curitibanos: EPAGRI, 2008.

LUCINI, M. A. Conselhos para o plantio de alho. Curitibanos: EPAGRI, 2010. Disponível em: http://www.anapa.com.br/principal/images/stories/te cnologia/conselhos.pdf. Acesso em: 21 set 2015.
LUDWIG, J.; MOURA, A.B.; SANTOS, A.S.; RIBEIRO, A.S. Microbiolização de sementes para o biocontrole da mancha-parda e da escaldadura em arroz irrigado. Tropical Plant Pathology. v. 34,p.322-328, 2009.

LUDWIG, J.; MOURA, A. B.; GOMES, C. B. Potencial da microbiolização de sementes de arroz com rizobactérias para o biocontrole do nematoide das galhas. Tropical Plant Pathology. v. 38, n.3, p.264-268, 2013.

MANDELBAUM, R. T.; ALLAN, D. L.; WACKETT, L. P. Isolation and Characterization of a Pseudomonas sp. that mineralizes the s-triazine herbicide atrazine. Applied and Environmental Microbiology.v. 61, n. 4, p. 1451-1457, $1995 . \quad$ Disponível em: http://aem.asm.org/content/61/4/1451.full.pdf+html . Acesso em: 03 nov. 2015.

MOREIRA, F. M. De S.; Da SILVA, K.; NÓBREGA, R.S.A.; De CARVALHO, F. Bactérias diazotróficas associativas: diversidade, ecologia e potencial de aplicações. Comunicata Scientiae. v.1, n.2, p.74-99, 2010.

OLIVEIRA, S. J. Microbiologia Veterinária. Guia Bacteriológico prático.

2 ed. Canoas: ULBRA., 2000.

OLIVEIRA, A. L. M. de; URQUIAGA, S.; BALDANI, J. I. Processos e mecanismos envolvidos na influência de microrganismos sobre o crescimento vegetal. Seropédica: CNPAB, ago. 2003. 40 p. (Embrapa Agrobiologia. Documentos, 161).

OTEINO, N.; LALLY，R. D.; KIWANUKA， S.; LLOYD, A.; RYAN, D.; GERMAINE, K.J.; DOWLING, D. N. Plant growth promotion induced by phosphate solubilizing endophytic Pseudomonas isolates. Frontiers in Microbiology. v. 6, article 745, p.1 -9, 2015.

PEDRINHO, E. A. N. Isolamento e caracterização de bactérias promotoras de crescimento em milho (Zea mays L.). 2009. 74f. Tese (Doutorado) - Pós-Graduação em Microbiologia, Faculdade de Ciências Agrárias e Veterinárias, Universidade Estadual Paulista. Jaboticabal, 2009. Disponível em: http://repositorio.unesp.br/bitstream/handle/11449/ 103918/pedrinho_ean_dr_jabo.pdf?sequence $=1$. Acesso em: 23 set. 2015 .

PONS, A. L. Instituto de Pesquisa Agropecuária. IP $A G R O$, n. 23 , p. 51,1980 . 
QUADROS, Patricia Dörr de et al. Desempenho agronômico a campo de híbridos de milho inoculados com Azospirillum. Rev. Ceres. 2014, vol.61, n.2, pp.209218. ISSN

$0034-737 \mathrm{X}$ http:/ / dx.doi.org/10.1590/S0034-737X2014000200008.

RAMOS, A. S. et al. Ação do Azospirillum lipoferum no desenvolvimento de plantas de milho. Revista Verde. v.5, n.4, p. 113 - 117, 2010. Disponível em:<https:// http://www.gvaa.com.br/revista/index.php/RVADS/ article/view/348/371>. Acesso em: 22 set. 2015.

RIBEIRO, M. C. STELATO, M. M. Microbiologia prática: aplicações de aprendizagem de microbiologia básica-bactérias, fungos e vírus. $2^{\circ}$ edição. São Paulo; Editora Atheneu, 2011. $224 \mathrm{p}$

RODRÍGUEZ, H.; FRAGA, R. Phosphate solubilizing bacteria and their role in plant growth promotion. Biotechnology Advances, v.17, p. 319-339, 1999. Disponível em:

http:/ / wnw.bashanfoundation.org/ hilda/ hildaphosphate.pdf. Acesso em: 04 nov. 2015.

SANCHEZ LÓPEZ, D. B. S.; HOYOS, A. M. G.; PERDOMO, F. A. R.; BUITRAGO, R. R. B. Efecto de rizobacterias promotoras de crecimiento vegetal solubilizadoras de fosfato en Lactuca sativa cultivar White Boston. Revista Colombiana de Biotecnología. Bogotá, v. 16, n.2, p.122-128, 2014.

SICUIA, O-A.; DINU, S.; CONSTANTINESCU, F. Phytohormone-like producing Bacillus increase tomato seedlings quality. Scientific Bulletin. Series F. Biotechnologies, v. XX, p.83 - 88, 2016.

SILVA, L. A. D. Queratinases de Bacillus subtillis S14: produção, expressa e análise de enzimas mutantes. 2013. 101p. Tese (Doutorado) - Pós-Graduação em Biologia Celular e Molecular, Centro de Biotecnologia, Universidade Federal do Rio Grande do Sul. Porto Alegre, 2013. Disponível em: http://www.lume.ufrgs.br/bitstream/handle/10183/9 0480/000912476.pdf?sequence $=1$. Acesso em: 13 nov. 2015.
SILVA, A. A. O.; FELIPE, T. A.; BACH, E. E. Ação do Azospirillum brasilense no desenvolvimento das plantas de trigo (variedade IAC-24) e cevada (variedade CEV 95033). ConScientiae Saúde, n. 3, p. 29-35, 2004. Disponível em: bttp:/ / www.redalyc.org/pdf/929/92900304.pdf. Acesso em: 11 nov. 2015.

SILVA, P. da et al. Isolamento, caracterização e resistência a antimicrobianos de bactérias Gramnegativas aeróbias e anaeróbias facultativas de amostras de solo. Revista do Instituto Adolfo Lutz. v.64, n.2, p. 245251, 2005. Disponível em: http://revistas.bvsvet.org.br/rialutz/article/download/23479/24336.

Acesso em: 14 nov. 2015.

SOUCHIE, E. L.; ABBOUD, A. C.S.; CAPRONI, A. L. Solubilização de fosfato in vitro por microrganismos rizosféricos de guandu. Ciência Agrária. Londrina, v.23, p.53-60, 2007.

TIRLONI, C. Adição de ácido cítrico mais ativador enzimático e calagem na disponibilidade e movimentação de ions no solo. 2006.59p. Dissertação (Mestrado) - PósGraduação em Agronomia, Universidade Federal da Grande Dourados. Dourados, 2006.2 Disponível em: http://livros01.livrosgratis.com.br/cp027434.pdf. Acesso em: 22 set. 2015

TURATTO, M. F.; BOTELHO, G.R. Efeito de Pseudomonas do grupo flourescente na eclosão de Meloidogyne javanica in vitro. In: XXXII Congresso Brasileiro de Nematologia, 2015, Londrina,.Londrina: SBN, 2015. P.165. Disponível em: http://nematologia.com.br/wp-

content/uploads/2015/06/anaiscbn32.pdf. Acesso em: 30 de dezembro de 2016.

VACHERON, J.; MOËNNE-LOCCOZ, Y.; DUBOST, A.; GONÇALVES-MARTINS, M.; MULLER, D.; PRIGENT-COMBARET, C. Fluorescent Pseudomonas strains with only few plantbeneficial properties are favored in the maize rhizosphere. Frontiers in Plant Science, v.7, article1212, p. 1-13, 2016.

VOISARD, C. et al. Biocontrol of root disease by Pseudomonas fluorescens CHA0: current concepts and experimental approaches. In: O'GARA, F., DOWLING, D. N., BOESTEN, B. (eds). Molecular ecology of rhizosphere microorganisms. Germany: VCH, 1994. p. 67-89. 